\title{
ASSESSMENT OF NITROGEN DIOXIDE DISTRIBUTION IN PIENIŃSKI NATIONAL PARK USING THE INDICATOR METHOD
}

\author{
Zbigniew Zuśka ${ }^{1 凶}$, Janusz Kozak², Ewelina Zając³ \\ ${ }^{1}$ Department of Ecology, Climatology and Air Protection, Faculty of Environmental Engineering and Land Surveying University \\ of Agriculture in Krakow, al. Mickiewicza 24/28, 30-059 Kraków \\ 2 Faculty of Materials, Civil and Environmental Engineering, University of Bielsko-Biała, ul. Willowa 2, 43-309 Bielsko-Biała \\ 3 Pieniński National Park, ul. Jagiellońska 107B, 34-450 Krościenko nad Dunajcem
}

\begin{abstract}
Aim of the study

The aim of the study was to assess the spatio-temporal variation in air quality in Pieniński National Park (PPN) and its buffer zone.
\end{abstract}

\begin{abstract}
Material and methods
An indicator method involving passive sampling was used. This is a Japanese method for determining concentrations, proposed by Amaya-Sugiura and modified by Krochmal and Górski. Air quality assessment was based on the ambient air concentration of nitrogen dioxide $\left(\mathrm{NO}_{2}\right)$, an air pollution indicator gas.
\end{abstract}

\section{Results and conclusions}

A long-term study on the effect of air pollution on a tree stand in the Carpathian Mountains of Central Europe has shown that long-term high concentrations of ozone, sulphur dioxide and nitrogen oxides can make trees susceptible to insect attacks and adversely affect the health of forests. The highest concentration exceeding the monthly average of $35 \mu \mathrm{g} \cdot \mathrm{m}^{-3}$ was noted in Krościenko nad Dunajcem in practically all seasons. This supports earlier results of research conducted in this area by Kozak, Miczyński and Jurkiewicz. In recent years the $\mathrm{NO}_{2}$ concentration in the centre of Krościenko in the month of November has increased from about 26-28 $\mu \mathrm{g} \cdot \mathrm{m}^{-3}$ in 2001-2004 to over $40 \mu \mathrm{g} \cdot \mathrm{m}^{-3}$ in 2016-2018. Similarly, in the outskirts of Krościenko, where the PPN headquarters is located, it increased from 13-17 $\mu \mathrm{g} \cdot \mathrm{m}^{-3}$ to $20-30 \mu \mathrm{g} \cdot \mathrm{m}^{-3}$. An upward trend is also perceptible in Szczawnica and at major transport hubs. This is mainly linked to the rapid growth of the motor vehicle industry and tourist expansion in the region. Concentrations in the area of the Trzy Korony summit and other sites in the higher parts of the Pieniny Mountains are similar and do not exceed $10 \mu \mathrm{g} \cdot \mathrm{m}^{-3}$ at any time during the studied period.

Keywords: nitrogen dioxide, spatial distribution, indicator method, monitoring

\section{INTRODUCTION AND RESEARCH OBJECTIVE}

Monitoring air quality in large urban agglomerations is currently well developed. Reference measurements using aspiration methods require extensive technical infrastructure, which is often not possible in agricultural and forested areas, and certainly not in national parks. Long-term measurements of indicator gaseous pollutants performed using contact methods by various institutions have made it possible to analyse the

凶e-mail:rmzuska@cyf-kr.edu.pl 
variation in $\mathrm{NO}_{2}$ concentrations in Pieniński National Park and surrounding areas. Nitrogen dioxide was chosen due to the role of traffic pollution and the increasing transition to gas heating in private homes and boarding houses in this tourism destination.

Nitrogen dioxide is a gas of a reddish-brown colour and a suffocating odour (Air quality in Europe 2013). The toxic effect of nitrogen dioxide involves restricting oxygenation of the body. It reduces immunity to bacterial infections, irritates the eyes and respiratory tract, and causes respiratory disorders and allergic diseases, including asthma, especially in children living in areas affected by smog.

Nitrogen oxides are among the most important pollutants produced by transport. They are released during fuel combustion in the engines of internal combustion vehicles, as well as in industrial and energy production. Nitrogen oxides (NOx) include nitrogen oxide (NO) and nitrogen dioxide $\left(\mathrm{NO}_{2}\right)$ (Vintar, Ogrin, 2015). Gases emitted to the atmosphere, such as nitrogen and sulphur oxides, carbon dioxide and carbon monoxide, as well as particulate matter, adversely affect the state of water, soil, forests, and human health (Juda-Rezler, 2010). Nitrogen oxides are partly responsible for photochemical smog and elevated ozone levels in the atmosphere. In the presence of sunlight as a catalyst, nitrogen oxides, together with hydrocarbons and carbon monoxide, are precursors of tropospheric ozone (Walczewski, 2005; WHO, 2006). These gases are emitted in particular by the engines of internal combustion vehicles.

Pollutants introduced to the air undergo various transformations. By reacting with hydroxyl radical $(\mathrm{OH})$, which is fairly common in the air, nitrogen dioxide forms nitric acid, a component of acid rain (Konieczyński 2004).

Palarz and Celiński-Mysław (2017) demonstrated that the highest nitrogen dioxide concentration in the valleys of the Polish Carpathians are found in winter, due to lower insolation, low temperatures, and increased emissions of air pollutants from home furnaces.

A long-term study on the effect of air pollution on a tree stand in the Carpathians of Central Europe showed that long-term high concentrations of ozone (above $40 \mathrm{ppm}$ ), sulphur dioxide (above $20 \mu \mathrm{g} \cdot \mathrm{m}^{-3}$ ) and nitrogen oxides (above $30 \mu \mathrm{g} \cdot \mathrm{m}^{-3}$ ) can predispose trees to insect attacks and adversely affect the health of forests. A study conducted in 1998-1999 in Poland (Tatra Mountains) and Romania (Retezat Mountains) showed average annual $\mathrm{NO}_{2}$ concentrations of $3.5-45.7 \mu \mathrm{g} \cdot \mathrm{m}^{-3}$ in Poland, and $2.7-13.0 \mu \mathrm{g} \cdot \mathrm{m}^{-3}$ in Romania (Bytnerowicz et al., 2003).

A study on air pollution using the indicator method was carried out in Pieniński National Park in 2007 as part of regional monitoring (Regional Inspectorate for Environmental Protection in Krakow). The measurement point was located in the Majerz clearing. A measurement lasting an entire year was used to determine the annual average concentrations of $\mathrm{NO}_{2}$ and $\mathrm{SO}_{2}$. The annual average concentration of $\mathrm{NO}_{2}$ was $30 \%$ of the level recognized as acceptable at that time in national parks $\left(20 \mu \mathrm{g} \cdot \mathrm{m}^{-3}\right)$.

The aim of the study was to assess the spatio-temporal variation of air quality in Pieniński National Park (PPN) and its buffer zone.

\section{RESEARCH METHODS}

Due to high topographic variation, the lack of technical infrastructure in many parts of the study area, and changes in reference aspiration measurements after 2002, a passive sampling method was used for the analysis. The assessment of air quality was based on the ambient air concentration of nitrogen dioxide $\left(\mathrm{NO}_{2}\right)$, an air pollution indicator gas. The method had previously been successful (Miczyński, et al., 1998; Kozak and Jurkiewicz, 2006) when the first studies were conducted in 1996-1997 and 1998-2004. The measurements were made using a Japanese method for determining concentrations proposed by Amaya-Sugiura and modified by Krochmal and Górski of the Cracow University of Technology (PN-89 Z-04029/08). Measurements were made in Pieniński National Park using this method in 1996-2018, but unfortunately there had been changes to exposure periods and measuring sites. For this reason, following verification and extrapolation of the measurement data using statistical methods, a multi-annual period was adopted as representative of the month of November. The passive method, due to its low measurement resolution (month-long period) and low cost, was used to assess air quality in zones classified as having the lowest concentrations. Agreement has been observed between reference methods for annual and periodic 
averages (Śnieżek and Degorska, 2009). The resulting starting material was used to create a map of the spatial distribution of $\mathrm{NO}_{2}$. The graphics were prepared in Surfer 8.0 software using linear interpolation (kriging) to create isolines.

\section{RESULTS}

The measurement sites in 2001-2009 were distributed around Pieniński National Park and its buffer zone, including Krościenko and Szczawnica. In subsequent years, annual tests were suspended, and exposure was carried out during different periods and at different sites. Using fixed measurements and a series of measurements made in the same way, the results were extrapolated by statistical methods, so that an attempt could be made to create a map for the years 2012-2018. This resulted in a cartographic representation of the spatial distribution of $\mathrm{NO}_{2}$ in the area based on measurements that were all conducted in the same way (see: Fig. 1).

The maps of $\mathrm{NO}_{2}$ distribution present information on the spatio-temporal distribution of the pollutant. The highest concentration exceeding the monthly average of $35 \mu \mathrm{g} \cdot \mathrm{m}^{-3}$ was noted in Krościenko nad Dunajcem in practically all measuring seasons. This supports an earlier study conducted in this area (Kozak et al., 2002). It should be noted, however, that in recent years the $\mathrm{NO}_{2}$ concentration in the centre of Krościenko has increased from about $26-28 \mu \mathrm{g} \cdot \mathrm{m}^{-3}$ in $2001-$ -2004 to over $40 \mu \mathrm{g} \cdot \mathrm{m}^{-3}$ in $2016-2018$. Similarly, in the outskirts of Krościenko, where the PPN headquarters is located, it increased from $13-17 \mu \mathrm{g} \cdot \mathrm{m}^{-3}$ to $20-30 \mu \mathrm{g} \cdot \mathrm{m}^{-3}$. An upward trend is also perceptible in Szczawnica and at major transport hubs. This is mainly linked to the rapid growth of the motor vehicle industry and tourist expansion in the region.

Research by Jurkiewicz et al. (2002) revealed that during the summer period, the intensity of vehicle traffic over the weekends is 363-561 vehicles/hour, of which $85-89 \%$ are passenger cars. During the summer holidays, the volume of tourist traffic reached 1,477 people per day (Warcholik et al.).

Concentrations in the area of the Trzy Korony summit and other sites in the higher parts of the Pieniny Mountains were similar and did not exceed $10 \mu \mathrm{g} \cdot \mathrm{m}^{-3}$ at any time during the analysed period.
Table 1. $\mathrm{NO}_{2}$ concentration $\left[\mu \mathrm{g} \cdot \mathrm{m}^{-3}\right]$ for November at selected monitoring points measured using the passive method in the Małopolska Region in 2007-2009, based on the Regional Inspectorate for Environmental Protection

\begin{tabular}{cccccc}
\hline Year & $\begin{array}{c}\text { Stary } \\
\text { Sącz }\end{array}$ & Limanowa & Gorlice & Szczawnica & $\begin{array}{c}\text { Majerz } \\
\text { PPN }\end{array}$ \\
\hline 2009 & 15.4 & 22.2 & 18.3 & 20.7 & 7.8 \\
\hline 2008 & 13.4 & 22.6 & 24.7 & - & 5.5 \\
\hline 2007 & 17.7 & 22.7 & 16.0 & - & 7.7 \\
\hline
\end{tabular}

Data from air monitoring by the Regional Inspectorate for Environmental Protection in Krakow, during which $\mathrm{NO}_{2}$ measurements were made by the indicator method in the entire Małopolska Region in 2007-2009 (Cieśla, and Tyrkiel-Cebula., 2008, Cieśla, Bryja., 2009-10), shows that the concentrations in the mountain valleys in Krościenko and Szczawnica were similar to the levels in larger urban centres such as Limanowa and Gorlice (see: Table 1).

Similar results were obtained by Miczyński et al. (1998) who analysed the concentrations of pollutants in mountain valleys in the Pieniński National Parku. Additionally, the high concentrations of pollutants recorded by them in the high parts of the Pieniny Mountains were recognized as migration pollutants.

Based on the measurements of $\mathrm{NO}_{2}$ concentrations in the ambient air of Pieniński National Parku throughout the 2001-2018 study period, a map of average concentrations from the entire period was created (see: Fig. 2).

Pieniński National Park is not exposed to high concentrations of $\mathrm{NO}_{2}$ in the ambient air. Only the road from Krośnica to Niedzica crossing through PPN, where traffic is heavy during the season due to transit of tourists and of rafts for rafting on the Dunajec, can have a greater influence on the $\mathrm{NO}_{2}$ concentration (Jurkiewicz et al., 2002). However, due to the scale of the measurements, this was not shown in the cartographic representation. The highest concentrations are observed in the densely developed areas and transport hubs of Krościenko and Szczawnica. The topography of the land and topoclimatic conditions are conducive to smog during temperature inversion, and the concentration of nitrogen dioxide in the ambient air of the valleys increases by $100-200 \%$ (see: Fig. 3). 

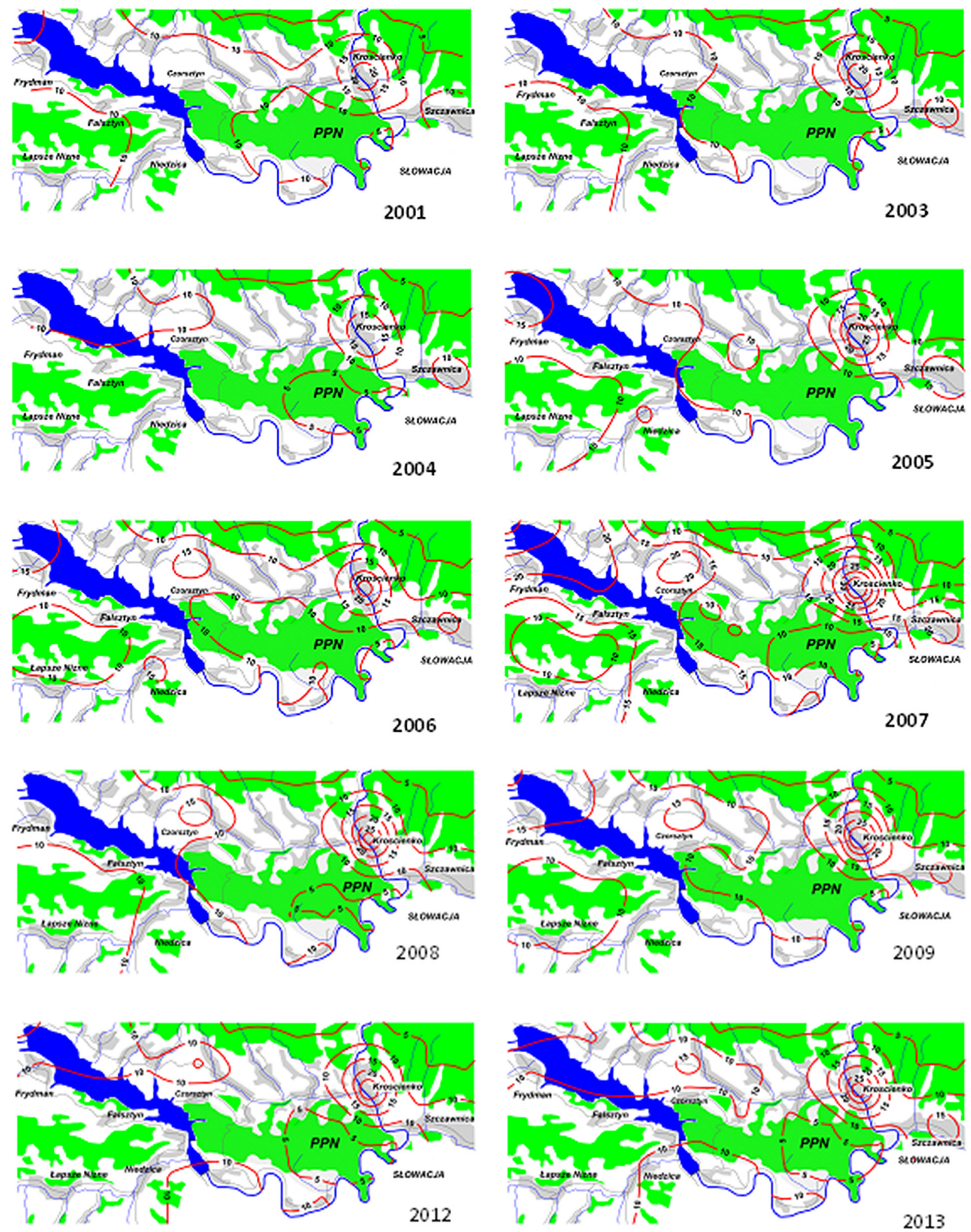

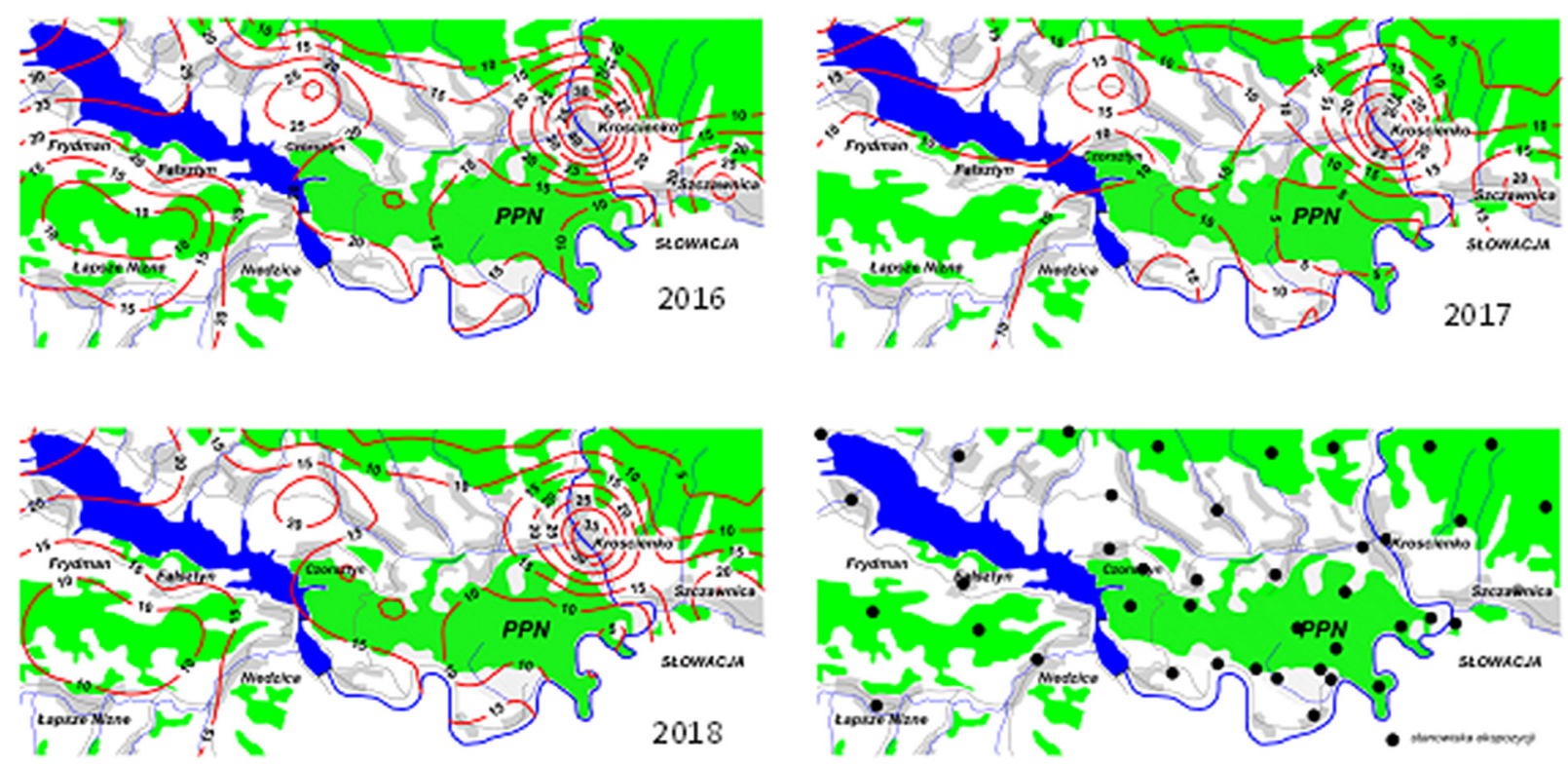

Fig. 1. Spatial distribution of $\mathrm{NO}_{2}$ concentrations $\left[\mu \mathrm{g} \cdot \mathrm{m}^{-3}\right]$ during the studied period (November 2001-2018) with locations of measurement points $(\bullet)$

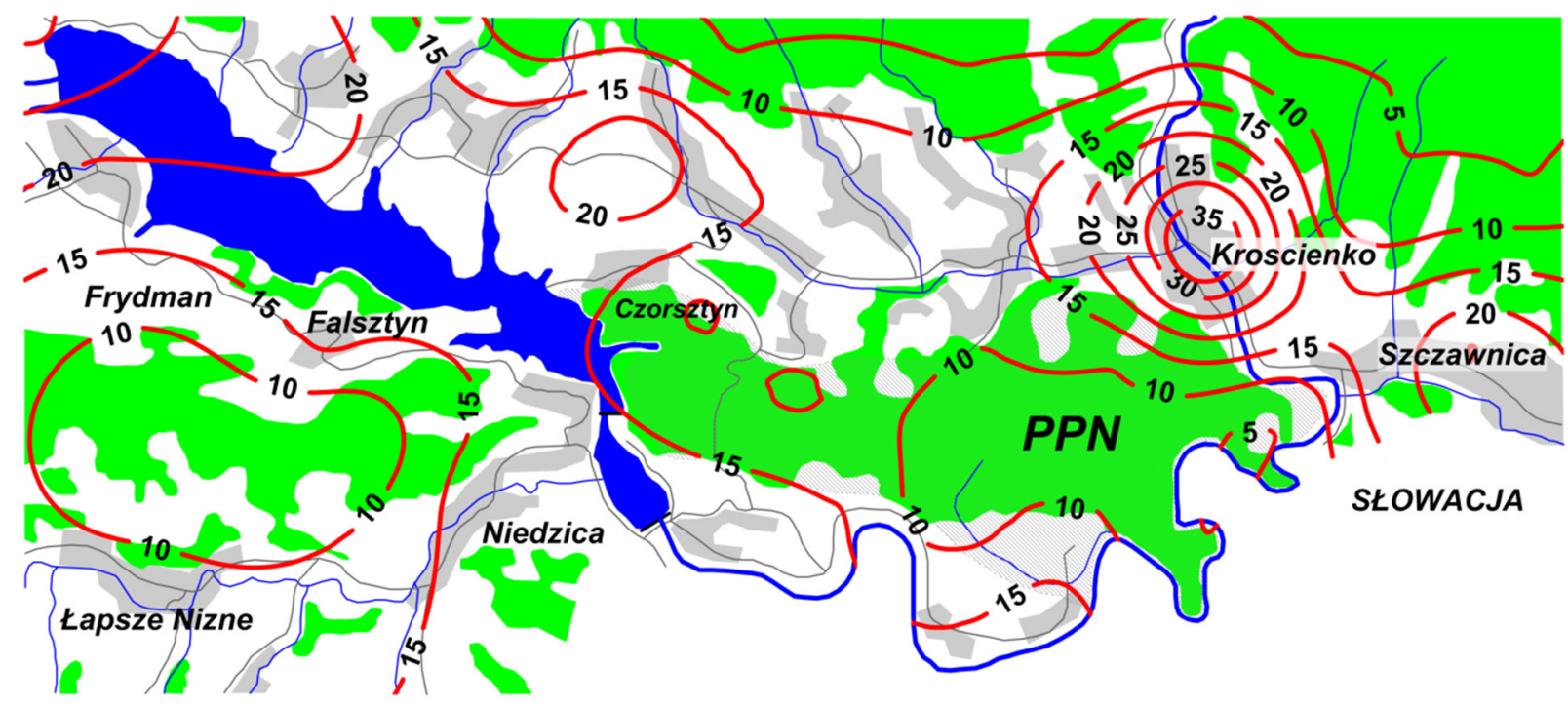

Fig. 2. Spatial distribution of $\mathrm{NO}_{2}$ concentrations $\left[\mu \mathrm{g} \cdot \mathrm{m}^{-3}\right]$ averaged for $2001-2018$ 
Zuśka, Z., Kozak, J., Zając, E. (2020). Assessment of nitrogen dioxide distribution in Pieniński National Park using the indicator method. Acta Sci. Pol., Formatio Circumiectus, 19 (4), 85-92. DOI: https://doi.org/10.15576/ASP.FC/2020.19.4.85

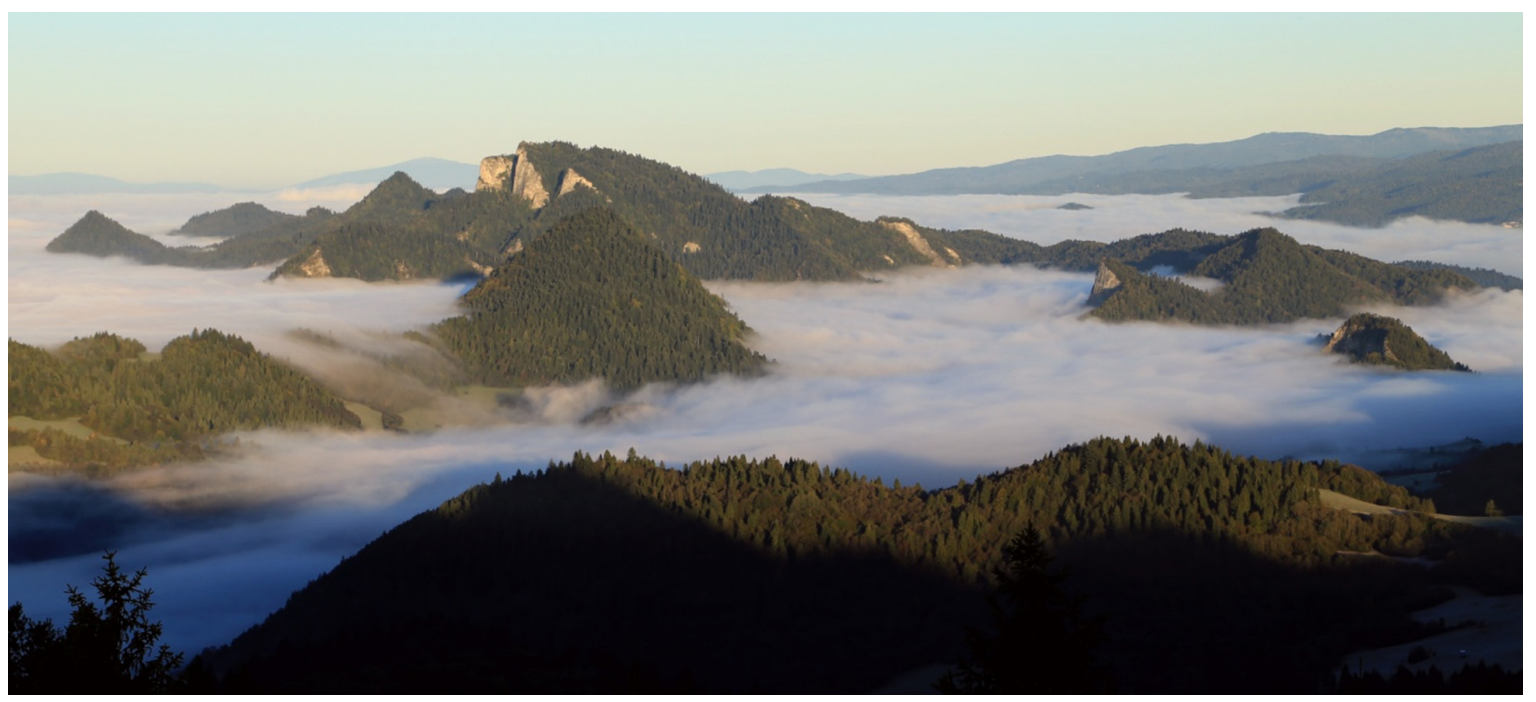

Fig. 3. Inversion fog in the Pieniny Mountains (photo by E. Zając)

The increase in automobile traffic and replacement of coal boilers with gas heating will most likely lead to an increase in $\mathrm{NO}_{2}$ concentrations in the area (Poskart, Zajemska, 2013).

\section{CONCLUSIONS}

1. No increase in $\mathrm{NO}_{2}$ concentrations was noted in Pieniński National Park in the years 2001-2018.

2. Topoclimatic conditions significantly affect concentrations in river valleys, where $\mathrm{NO}_{2}$ concentrations in the air are 100-200\% higher during temperature inversion.

3. Tourism development in places such as Szczawnica, Krościenko, and Sromowce Niżne, with the accompanying increase in motor vehicle traffic, as well as the transition to gas heating, may in the future lead to the risk of increased ambient air $\mathrm{NO}_{2}$ concentrations in this area.

Funded with a subsidy from the Ministry of Science and Higher Education for the University of Agriculture in Krakow for 2020.

\section{REFERENCES}

Air quality in Europe - 2013 report, European Environment Agency (2013). https://www.eea.europa.eu/publications/ air-quality-in-europe-2013
Bytnerowicz A., Badea O., Barbu I., Fleischer P., Frączek W., Gancz V., Godzik B., Grodzińska K., Grodzki W., Karnosky D., Koren M., Krywult M., Krzan Z., Longauer R., Mankovska B., William J. Manning, McManus M., Musselman R.C., Vasile C., (2003), New international long-term ecological research on air pollution effects on the Carpathian Mountain forests, Central Europe, Environment International, 29, 2-3, June 2003, 367-376,

https://www.sciencedirect.com/science/article/pii/S01604 12002001721

Cieśla G., Bryja A. (2010). Sprawozdanie z badań zanieczyszczenia powietrza metodą wskaźnikową w zakresie $\mathrm{NO}_{2}$ i SO $\mathrm{S}_{2} \mathrm{w}$ ramach Monitoringu Regionalnego w 2009r WIOŚ w Krakowie delegatura w Nowym Sączu.

Cieśla G., Tyrkiel-Cebula L. (2008). Sprawozdanie z badań zanieczyszczenia powietrza metodą wskaźnikową w zakresie $\mathrm{NO}_{2} \mathrm{i} \mathrm{SO}_{2}$ w ramach Monitoringu Regionalnego w 2007r WIOŚ w Krakowie delegatura w Nowym Sączu.

Juda-Rezler K., Manczarski P. (2010). Zagrożenia związane z zanieczyszczeniem powietrza atmosferycznego i gospodarką odpadami komunalnymi, Nauka 4/2010, Polska Akademia Nauk, Warszawa, 97-106

Jurkiewicz T., Miczyński J., Kozak J. (2002). Pomiar natężenia ruchu pojazdów na drodze Krośnica - Niedzica i jego wpływu na jakość powietrza na terenie Pienińskiego Parku Narodowego. Pieniny - Przyroda i Człowiek 7, 31-42.

Konieczyński J. (2004). Ochrona powietrza przed szkodliwymi gazami, Wydawnictwo Politechniki Śląskiej, Gliwice; 29-30. 
Zuśka, Z., Kozak, J., Zając, E. (2020). Assessment of nitrogen dioxide distribution in Pieniński National Park using the indicator method. Acta Sci. Pol., Formatio Circumiectus, 19 (4), 85-92. DOI: https://doi.org/10.15576/ASP.FC/2020.19.4.85

Kozak J., Jurkiewicz T. (2006). Przestrzenne zróżnicowanie gazowych zanieczyszczeń powietrza na obsarze Pienińskiego Parku narodowego i okolic Zeszyty Naukowe ATH - Inżynieria Włókiennicza i Ochrona Środowiska 24 (7), 154-159.

Kozak J., Miczyński J., Jurkiewicz T., (2002). Ocena stanu zanieczyszczenia powietrza w Krościenku nad Dunajcem. Pieniny - Przyroda i Człowiek 7, 23-30;

Krochmal D., Górski L. (1996). Opracowanie metody oznaczania dwutlenku azotu w powietrzu atmosferycznym z użyciem pasywnego pobierania próbek - Chemia i Inżynieria Ekologiczna, Kraków 3.2.

Miczyński J., Kozak J., Jurkiewicz T., (1998). Przestrzenny rozkład stężenia dwutlenku siarki i azotu w rejonie Pienińskiego Parku Narodowego. Pieniny - Przyroda i Człowiek 6, 137-141.

Palarz A., Celiński-Mysław D. (2017), The effect of temeprature inversions on the particulate matter pm 10 and sulfur dioxide concentrations in selected basins in the Polish Carpathians, Carpathian Journal of Earth and Environmental Sciences, July 2017, 12, 2, 629 - 640.

Poskart A., Zajemska M, (2013). Kontrola stężenia NOx w procesie spalania gazu ziemnego, www.miesiecznikchemik.pl (dostęp 21052020 r.) 10, 67, 848-855.
Śnieżek T., Degorska A., (2009). Pasywna metoda pomiaru wybranych zanieczyszczeń powietrza na potrzeby oceny jakości Powietrza w Polsce. Monitoring Środowiska Przyrodniczego, 10, 19-27, Kieleckie Towarzystwo Naukowe, Kielce

Vintar Mally K., Ogrin M. (2015). Spatial variations in nitrogen dioxide concentrations in urban Ljubljana, Slovenia, Moravian Geographical Reports, 23, 3/2015, 27-35

Walczewski J. (2005). Meteorologiczne i klimatyczne warunki rozprzestrzeniania się zanieczyszczeń powietrza, Przegląd Geofizyczny Rocznik 2005, 3-4, Polskie Towarzystwo Geofizyczne Warszawa, 190

Warcholik W., Majewski K., Kiszka K. (2010). Monitoring of tourist traffic in the pieniny National park, Pieniny -przyroda i człowiek, 11, 149-156.

WIOŚ w Krakowie, Delegatura w Nowym Sączu, Dział Monitoringu Środowiska, (2008), Sprawozdanie Z Badań Zanieczyszczenia Powietrza Metodą Wskaźnikową w zakresie $\mathrm{NO}_{2} \mathrm{I} \mathrm{SO}_{2}$ w ramach monitoringu regionalnego W 2007 Roku

World Health Organization (WHO). (2006). Air quality guidelines for particulate matter, ozone, nitrogen dioxide and sulfur dioxide. Global update 2005. Summary of risk assessment.

\section{OCENA ROZKŁADU STĘŻENIA DWUTLENKU AZOTU W PIENIŃSKIM PARKU NARODOWYM METODĄ WSKAŹNIKOWA}

\section{ABSTRAKT}

\section{Cel pracy}

Celem pracy była ocena zmienności czasowo-przestrzennej jakości powietrza atmosferycznego na obszarze Pienińskiego Parku Narodowego (PPN), jak i jego otuliny.

\section{Materiak i metody}

Ocenę jakości powietrza przeprowadzono, opierając się na stężeniu w imisji jednego z gazów wskaźnikowych zanieczyszczenia powietrza atmosferycznego, jakim jest dwutlenek azotu $\left(\mathrm{NO}_{2}\right)$. W pomiarach zastosowano japońską pasywną metodę oznaczania stężeń Amaya-Sugiura w modyfikacji Krochmala i Górskiego.

\section{Wyniki i wnioski}

W długoterminowych badaniach nad wpływem zanieczyszczenia powietrza na drzewostan w Karpatach w Europie Środkowej wykazano, że długotrwałe wysokie stężenia ozonu, dwutlenku siarki i tlenków azotu mogą sprawiać, że drzewa stają się podatne na ataki owadów i pogarsza się stan zdrowia lasów. Największe stężenia przekraczające średnią miesięczną $35 \mu \mathrm{g} \cdot \mathrm{m}^{-3}$ zanotowano w Krościenku nad Dunajcem praktycznie we wszystkich sezonach pomiarowych. Potwierdza to wcześniejsze wyniki badań w rejonie Krościenka nad Dunajcem prowadzonych przez Kozaka, Miczyńskiego i Jurkiewicza. W ostatnich latach poziom stężenia $\mathrm{NO}_{2}$ w rejonie centrum Krościenka wzrasta z poziomu ok 26-28 $\mu \mathrm{g} \cdot \mathrm{m}^{-3} \mathrm{w}$ latach $2001-2004$ do poziomu ponad $40 \mu \mathrm{g} \cdot \mathrm{m}^{-3} \mathrm{w}$ latach 2016-2018 w badanym okresie miesiąca listopada. Podobnie na obrzeżach Kro- 
Zuśka, Z., Kozak, J., Zając, E. (2020). Assessment of nitrogen dioxide distribution in Pieniński National Park using the indicator method. Acta Sci. Pol., Formatio Circumiectus, 19 (4), 85-92. DOI: https://doi.org/10.15576/ASP.FC/2020.19.4.85

ścienka, w rejonie Dyrekcji PPN z poziomu $13-17 \mu \mathrm{g} \cdot \mathrm{m}^{-3}$ do poziomu $20-30 \mu \mathrm{g} \cdot \mathrm{m}^{-3}$. Również w Szczawnicy oraz przy większych węzłach komunikacyjnych zauważalna jest tendencja wzrostowa. Jest to związane z gwałtownym rozwojem motoryzacji i ekspansji turystycznej w tym regionie. Stężenia w rejonie Trzech Koron Pienińskich, jak i na innych stanowiskach wyższych partii Pienin, są notowane na zbliżonym poziomie i w całym okresie analitycznym nie przekraczają $10 \mu \mathrm{g} \cdot \mathrm{m}^{-3}$.

Słowa kluczowe: tlenki azotu, rozkład przestrzenny, metoda wskaźnikowa, monitoring 